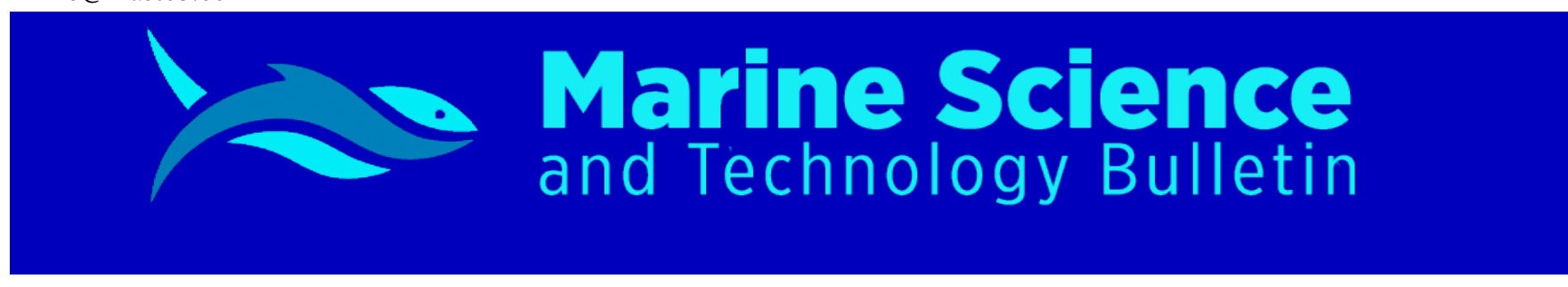

RESEARCH ARTICLE

\title{
Length-weight relationships of 12 fish species from the Köyceğiz Lagoon,
}

\section{Turkey}

\section{İsmail Reis ${ }^{1^{*}}$}

${ }^{1}$ Department of Fishing Technology, Faculty of Fisheries, Mugla Sitki Kocman University, Kotekli-Mentese 48000 Mugla, Turkey

\section{ARTICLE INFO}

Article History:

Received: 18.04.2020

Received in revised form: 22.06.2020

Accepted: 26.06.2020

Available online: 29.06.2020

\section{Keywords:}

Köyceğiz Lagoon

Length-weight relationships

Fish barrier

\begin{abstract}
A B S T R A C T
This study provides the length-weight relationships of 12 fish species that belong to ten families from the Köyceğiz Lagoon, Turkey; Dicentrarchus labrax (Linnaeus, 1758); Diplodus annularis (Linnaeus, 1758); Diplodus sargus (Linnaeus, 1758); Dussumieria elopsoides Bleeker, 1849; Engraulis encrasicolus (Linnaeus, 1758); Oreochromis niloticus (Linnaeus, 1758); Gobius niger Linnaeus, 1758; Mullus barbatus barbatus Linnaeus, 1758; Sparus aurata Linnaeus, 1758; Siganus rivulatus Forsskål \& Niebuhr, 1775; Solea solea (Linnaeus, 1758); Trachinotus ovatus (Linnaeus, 1758). A total of 720 fish samples were collected with fish barrier, trammel net, beach seine and cast-net. The growth type of $D$. annularis $(b=3.148)$, D. elopsoides $(b=3.089)$, G. niger $(b=3.154)$, S. solea $(b=3.124)$ was determined as positive allometry and E. encrasicolus ( $b=2.814)$, D. labrax $(b=2.764), T$. ovatus ( $b=2.901)$ was determined as negative allometry whereas $D$. sargus ( $b=2.995), M$. barbatus barbatus ( $b=3.003)$, O. niloticus ( $b=3.088)$, S. aurata $(b=3.009)$ and S. rivulatus $(b=3.079)$ showed isometry. The results of this investigation will contribute to further fishery studies in the Köyceğiz Lagoon.
\end{abstract}

Please cite this paper as follows:

Reis, İ. (2020). Length-weight relationships of 12 fish species from the Köyceğiz Lagoon, Turkey. Marine Science and Technology Bulletin, 9(2): 136-144.

\section{Introduction}

Lagoons and wetlands, which are of great ecological importance, are special ecosystems and undertake many functional tasks. The coastal lagoons located between the land and the sea are under the influence of both terrestrial and marine factors and are the transition zones between seawater and freshwater environments (Bianchi, 1988). Lagoons are also important for the economy due to providing a wide array of ecosystem services in addition to being the home of so many different species. Some of these services include fisheries, nutrient cycling and flood protection (Miththapala, 2013).

\footnotetext{
* Corresponding author

E-mail address: ismailreis@mu.edu.tr (İ. Reis)
} 
Lagoons play a positive role in increasing fish stocks as they are the places where the larvae of many fish species provide their nutrition, shelter and sustainability (Whitfield, 1999).

Length-weight relationships (LWRs) have an important role in fish stock management (Froese, 2006) and are also useful for comparing life history and morphological aspects of different populations from other regions (Goncalves et al., 1997). The LWRs provide predicting the weight corresponding to a given length and to allow for the comparison of fish growth in different habitats (Bagenal and Tesch, 1978; Morato et al., 2001; Tsoumani et al., 2006). LWRs may be useful to determine whether somatic growth is isometric or allometric (Ricker, 1975). Also the LRWs data provide the estimation of population size of a fish stock (Dulcíc and Kraljevic, 1996). Though there are some studies on length weight relationships in the Black Sea (Samsun et al., 2006; Kasapoğlu and Düzgüneş, 2013), the Sea of Marmara (Keskin and Gaygusuz, 2010; Bok et al., 2011) the Aegean Sea (İlkyaz et al., 2008; Bilge et al., 2014; Ates et al., 2017), the eastern Mediterranean Sea (Cicek et al., 2006; Sangun et al., 2007; Gökçe et al., 2010) and in the Turkish Lagoons few studies on LWRs of fish species in the Homa Lagoon (Acarli et al., 2014); in the Beymelek Lagoon (Sümer, 2012) have been conducted.

The aim of this study is to determine the LWRs of 12 fish species sampled from the Köyceğiz Lagoon, Southeastern Aegean Sea.

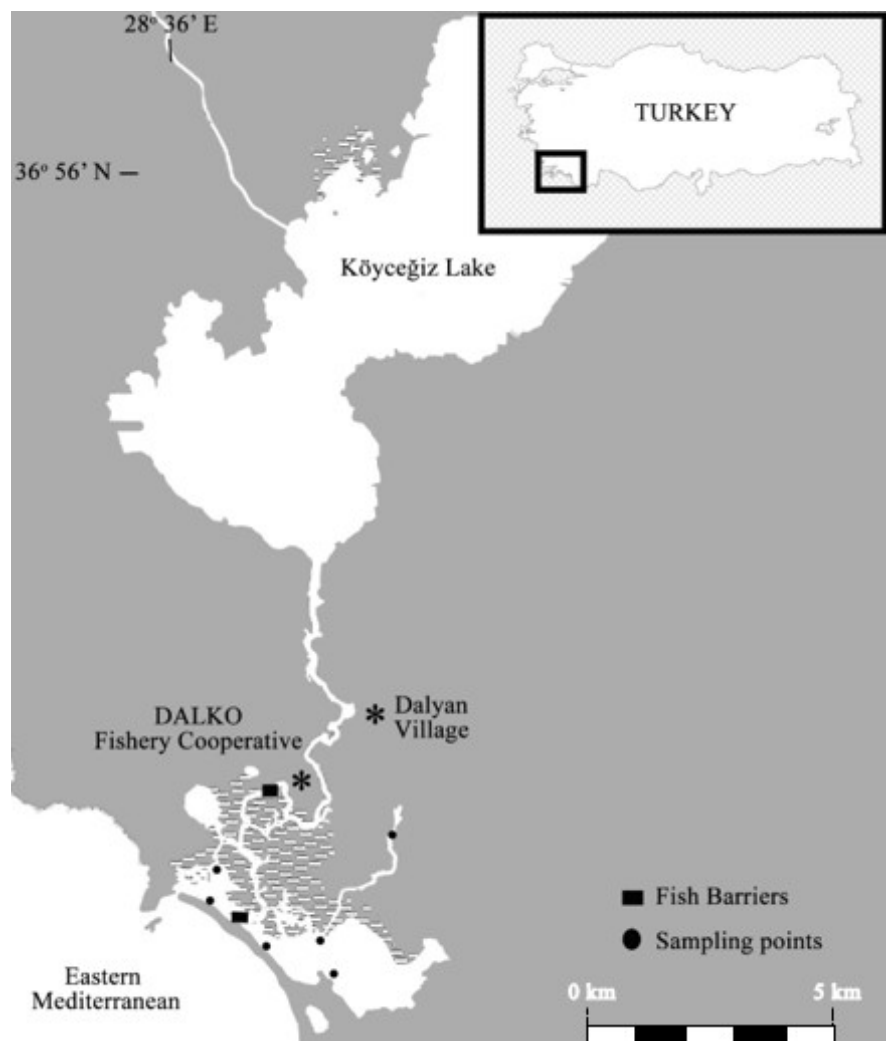

Figure 1. Sampling points of Köyceğiz Lagoon, Muğla, Turkey

\section{Material and Methods}

The Köyceğiz Lagoon system covers 5400 hectares lake area, 1150 hectares marsh-looking delta area and is connected to sea via a $14 \mathrm{~km}$ long canal. The width of the canal varies between 570 meters and the depth between 1-6 meters (Buhan, 1998). A total of 720 fish samples were collected with fish barrier $(40 \mathrm{~mm}$ mesh size), trammel net ( $32 \mathrm{~mm}$ mesh size), beach seine (10 $\mathrm{mm}$ mesh size) and cast-net (32 $\mathrm{mm}$ mesh size) between January 2017 and December 2017 in the Köyceğiz Lagoon, Turkey (Figure 1). Fish species were identified at the species level and validated by referencing FishBase (Froese and Pauly, 2017). Total length (TL) of fish species were recorded to the nearest centimetre $(0.1 \mathrm{~cm})$, and body weight $(\mathrm{W})$ was measured with precision balance of ( $0.01 \mathrm{~g}$ accuracy).

The parameters $a$ and $b$ of relationships of the equation $W=a L^{b}$ (Ricker, 1975) were estimated through logarithmic transformation;

$$
\log W=\log a+b \log T L
$$

where $W$ is weight $(\mathrm{g}), T L$ is total length $(\mathrm{cm}), a$ is the intercept and $b$ is the slope of the linear regression. Parameters $a$ and $b$ were calculated by least-squares regression, as was the coefficient of determination $\left(\mathrm{r}^{2}\right)$. The significance of the bvalues for each species was tested by Pauly's t-test to confirm that it was significantly different from the predictions for isometric growth $(b=3)$ (Pauly, 1984). Pauly's t-test was calculated as:

$$
t=\left(\frac{S D_{\log T L}}{S D_{\log W}}\right) \times\left[\frac{|b-3|}{\sqrt{1-r^{2}}}\right] \times \sqrt{(n-2)}
$$

where $S D_{\log T L}$ is the standard deviation of the $\log T L$ values, $S D_{\log W}$ is the standard deviation of the $\log W$ values, $n$ is the number of fish species used in the computation. The value of $b$ is different from 3 if $t$ value is greater than the tabled $t$ values for n-2 degrees of freedom (Pauly, 1984).

\section{Results}

A total of 12 fish species from ten families namely Carangidae, Cichlidae, Dussumieriidae, Engraulidae, Gobiidae, Moronidae, Mullidae, Siganidae, Soleidae and Sparidae were sampled in this study. The sample size ranged from 29 individuals for D. elopsoides, to 196 individuals for $E$. encrasicolus. The $b$ value of the LWRs ranged from 2.274 for $D$. labrax to 3.154 for $G$. niger. The curves of length-weight relationships for studied species are given in Figure 2. The growth type of D. annularis, D. elopsoides, G. niger, S. solea was determined as positive allometry $(b>3)$ and E. encrasicolus, $D$. 
labrax, T. ovatus was determined as negative allometry $(b<3)$ whereas D. sargus, M. barbatus barbatus, O. niloticus, S. aurata and $S$. rivulatus showed isometry $(b=3)$. The determination coefficient $\left(\mathrm{r}^{2}\right)$ ranged from 0.94 for $S$. aurata to 0.99 for $D$. elopsoides. The coefficient of determination $\left(\mathrm{r}^{2}\right)$ was very high for all studied species. Length-weight relationship parameters $a$ and $b$, standard deviation of $b\left(\mathrm{SD}_{\mathrm{b}}\right), 95 \%$ confidence interval (CI) for $b$, correlation coefficient $\left(\mathrm{r}^{2}\right)$, number of sample (n), length range and weight range for each of the twelve species were presented in Table 1.

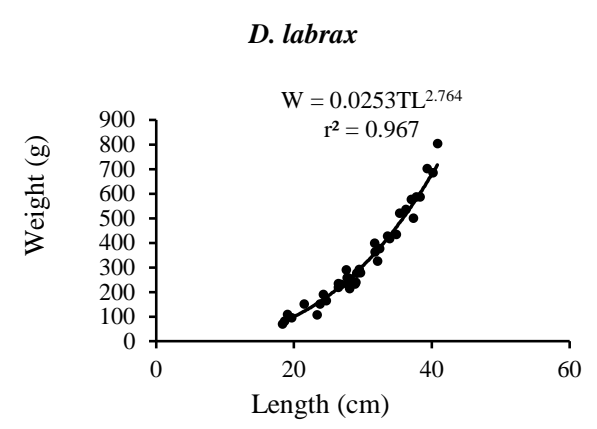

D. elopsoides

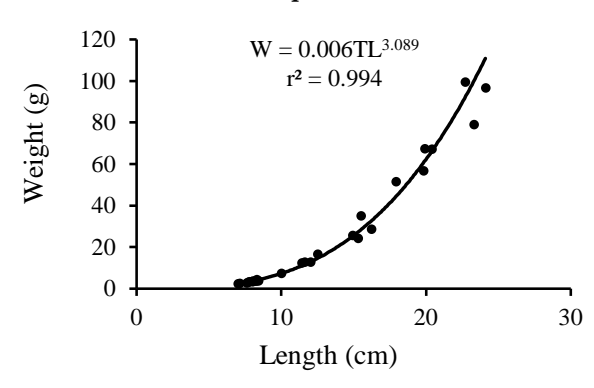

M. barbatus barbatus

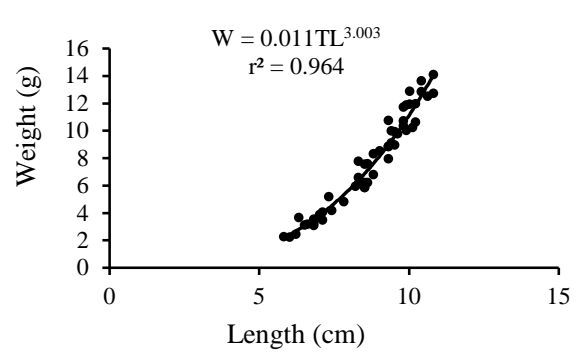

S. rivulatus

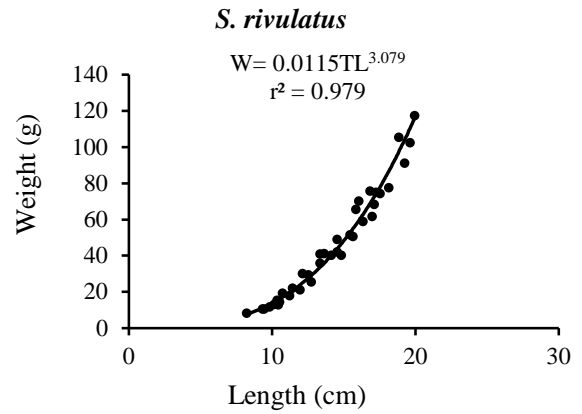

D. annularis

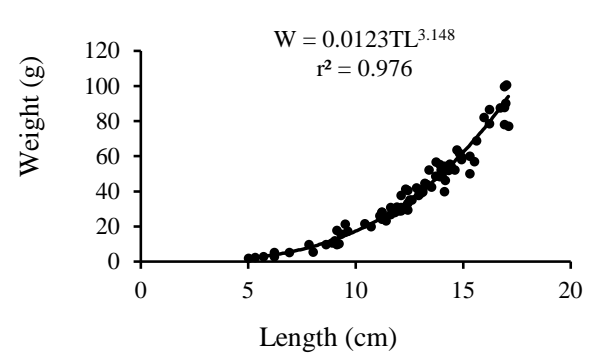

E. encrasicolus

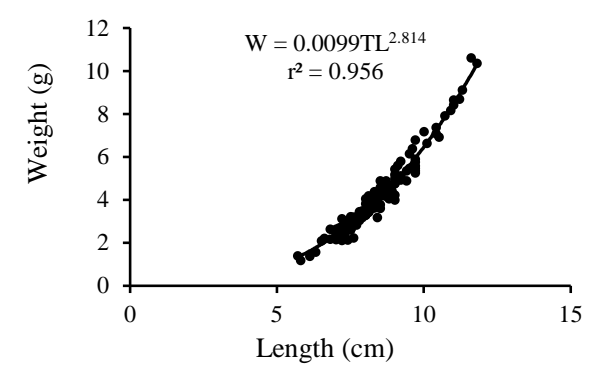

O. niloticus
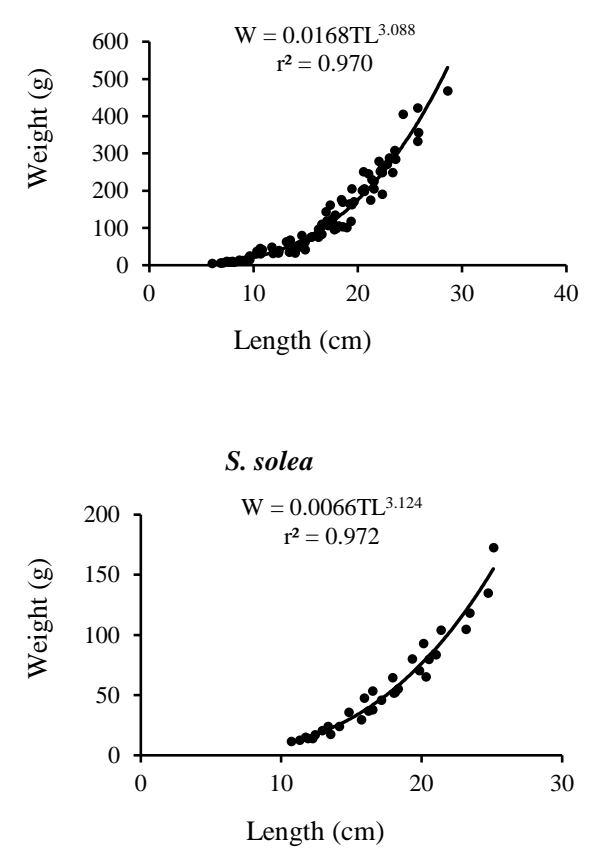

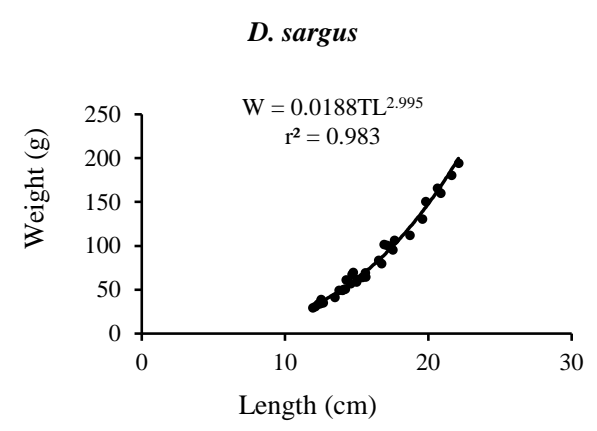

G. niger

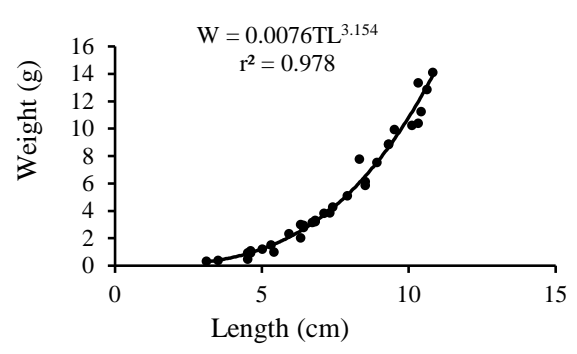

S. aurata
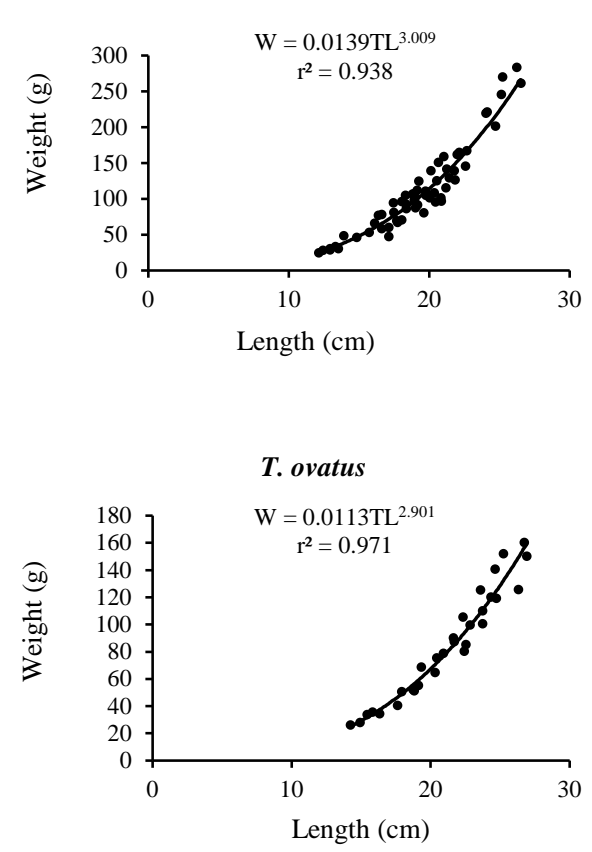

Figure 2. The curves of length-weight relationships for studied species from Köyceğiz Lagoon 
Table 1. Parameters of length-weight relationship for twelve fish species from the Köyceğiz Lagoon

\begin{tabular}{|c|c|c|c|c|c|c|c|c|c|}
\hline Species & $\mathbf{n}$ & TL range $(\mathrm{cm})$ & $\mathrm{W}$ range $(\mathrm{g})$ & $a$ & $\boldsymbol{b}$ & $\mathbf{r}^{2}$ & $\mathrm{SD}_{\mathrm{b}}$ & $\% 95 \mathrm{CI}$ of $b$ & Pauly's $t$-test \\
\hline D. labrax & 39 & $18.3-40.8$ & $69.76-805.32$ & 0.0253 & 2.764 & 0.967 & 0.049 & $2.59-2.94$ & $t=2.8002, \mathrm{P}<0.05$ \\
\hline D. annularis & 81 & $5.0-17.1$ & $1.85-100.57$ & 0.0123 & 3.148 & 0.976 & 0.061 & $3.04-3.26$ & $t=2.6505, \mathrm{P}<0.05$ \\
\hline D. elopsoides & 29 & $7.0-24.1$ & $2.41-99.50$ & 0.006 & 3.089 & 0.994 & 0.045 & $2.99-3.19$ & $t=1.9158, \mathrm{P}<0.05$ \\
\hline E. encrasicolus & 196 & $6.5-11.8$ & $2.09-10.61$ & 0.0099 & 2.814 & 0.956 & 0.033 & $2.72-2.90$ & $t=4.1570, \mathrm{P}<0.05$ \\
\hline O. niloticus & 93 & $6.0-28.6$ & $5.31-467.85$ & 0.0168 & 3.088 & 0.970 & 0.093 & $2.98-3.20$ & $t=1.5513, \mathrm{P}>0.05$ \\
\hline S. aurata & 61 & $12.1-26.5$ & $25.15-283.82$ & 0.0139 & 3.009 & 0.938 & 0.062 & $2.81-3.21$ & $t=0.0916, \mathrm{P}>0.05$ \\
\hline S. rivulatus & 37 & $8.2-19.9$ & $8.42-117.51$ & 0.0115 & 3.079 & 0.979 & 0.047 & $2.93-3.23$ & $t=1.0623, \mathrm{P}>0.05$ \\
\hline S. solea & 32 & $10.7-25.1$ & $11.42-172.51$ & 0.0066 & 3.124 & 0.972 & 0.057 & $2.92-3.32$ & $t=1.7488, \mathrm{P}<0.05$ \\
\hline T. ovatus & 30 & $14.9-26.9$ & $28.14-160.36$ & 0.0113 & 2.901 & 0.971 & 0.040 & $2.70-3.09$ & $t=1.7198, \mathrm{P}<0.05$ \\
\hline
\end{tabular}

Note: $n$ : sample size; $T L$ : total length (cm); $W$ : total weight $(\mathrm{g}) ; a$ : intercept; $b$ : slope of the regression line; $r^{2}$ : coefficient of determination; $S D_{b}$ : standard deviation of $b$; CI: confidence intervals.

\section{Discussion}

The length-weight relationships in fish could be affected by many factors such as season, habitat, temperature, salinity, gonad maturity, sex, diet, food availability and length range (Tesch, 1971; Moutopoulos and Stergiou, 2002; Froese, 2006). The growth coefficient $(b)$ values in LWR identify the growth type of the fish species. The value of $b \neq 3$ shows allometric growth where the fish becomes thinner with increasing length, $b=3$ shows isometric growth and fish transform into more robust with increase in length (Bagenal and Tesch, 1978). The $b$ value is expected to range from 2.5 to 3.5 (Froese, 2006). The $b$ values of studied species are in reported range by Froose (2006).

Growth types were found similar to present study for $D$. labrax (Crec'hriou et al., 2013; Mahé et al., 2018), D. annularis (İlkyaz et al., 2008), D. sargus (Ceyhan et al., 2009), D. elopsoides (Erguden et al., 2009), E. encrasicolus (Aka et al., 2004; Samsun et al., 2006), O. niloticus (Nobile et al., 2015), G. niger (Cicek et al., 2006; Bilge et al., 2014), M. barbatus barbatus (Djabali et al., 1993; Giacalone et al., 2010), S. aurata (Stergiou and Moutopoulos, 2001), S. rivulatus (Gabr et al., 2018), S. solea (Cerim and Ateş, 2020) and T. ovatus (Abdallah, 2002; Moutopoulos et al., 2013). In contrast, there are different results of growth types for D. labrax (Dulčić, and Glamuzina, 2006), D. annularis (Sangun et al., 2007), D. sargus (Maci et al., 2009), E. encrasicolus (Veiga et al., 2009), O. niloticus (Mehak et al., 2017), G. niger (Bok et al., 2011; Kasapoğlu and Düzgüneş, 2013), M. barbatus barbatus (Maci et al., 2009; Gökçe et al., 2010), S. aurata (Ceyhan et al., 2009; Crec'hriou et al., 2013), S. rivulatus (Ates et al., 2017), S. solea (Türkmen, 2003) and $T$. ovatus (Santos et al., 2002). Length-weight relationships obtained in the present study are compared by different researches in other locations and some differences determined (Table 2). It can be think that the differences are about sampling method, fish condition, seasonality, length range, sex, gonadal maturity, sample size and stomach fullness. 
Table 2. Comparison of length-weight relationships of studied species from different locations

\begin{tabular}{|c|c|c|c|c|c|c|c|}
\hline Species & $\mathbf{n}$ & TL range $(\mathrm{cm})$ & $a$ & $b$ & $\mathbf{r}^{2}$ & Location & References \\
\hline \multirow{5}{*}{ D. labrax } & 422 & $24.5-88.0$ & 0.0079 & 3.065 & 0.976 & $\begin{array}{l}\text { Eastern Adriatic estuarine } \\
\text { systems }\end{array}$ & Dulčić and Glamuzina, 2006 \\
\hline & 67 & $27.0-53.0$ & 0.0150 & 2.880 & 0.924 & French Catalan coast & Crec'hriou et al., 2013 \\
\hline & 111 & $8.5-33.9$ & 0.0150 & 2.947 & 0.999 & Homa Lagoon & Acarli et al., 2014 \\
\hline & 417 & $16.0-83.0$ & 0.0340 & 2.701 & & $\begin{array}{l}\text { North-eastern Atlantic } \\
\text { Ocean }\end{array}$ & Mahé et al., 2018 \\
\hline & 39 & $18.3-40.8$ & 0.0253 & 2.764 & 0.966 & Köyceğiz Lagoon & Present study \\
\hline \multirow{5}{*}{ D. annularis } & 154 & $10.3-15.0$ & 0.0370 & 2.677 & 0.90 & $\begin{array}{l}\text { North-Eastern } \\
\text { Mediterranean Coast }\end{array}$ & Sangun et al., 2007 \\
\hline & 161 & $9.8-16.0$ & 0.0253 & 3.012 & 0.95 & $\begin{array}{l}\text { Gulf of Gabes, Central } \\
\text { Mediterranean }\end{array}$ & Ghailen et al., 2010 \\
\hline & 15 & $7.0-16.7$ & 0.0220 & 2.957 & 0.994 & Sea of Marmara & Bok et al., 2011 \\
\hline & 121 & $3.9-15.5$ & 0.0100 & 3.190 & 0.994 & Homa Lagoon & Acarli et al., 2014 \\
\hline & 81 & $5.0-17.1$ & 0.0123 & 3.148 & 0.976 & Köyceğiz Lagoon & Present study \\
\hline \multirow{5}{*}{ D. sargus } & 33 & $14.9-26.7$ & 0.0342 & 2.808 & 0.850 & $\begin{array}{l}\text { South coast of Iskenderun } \\
\text { Bay }\end{array}$ & Can et al., 2002 \\
\hline & 33 & $16.0-32.3$ & 0.0144 & 3.061 & 0.980 & Gökova Bay, Aegean Sea & Ceyhan et al., 2009 \\
\hline & 368 & $10.0-40.0$ & 0.0170 & 3.000 & 0.934 & French Catalan coast & Crec'hriou et al., 2013 \\
\hline & 124 & $11.0-38.5$ & 0.0110 & 3.145 & 0.975 & Southern Ionian sea, Greece & $\begin{array}{l}\text { Dimitriadis and Konstantinidou, } \\
2018\end{array}$ \\
\hline & 35 & $11.9-22.1$ & 0.0188 & 2.995 & 0.983 & Köyceğiz Lagoon & Present study \\
\hline \multirow[t]{2}{*}{ D. elopsoides } & 59 & $9.9-16.4$ & 0.0055 & 3.123 & 0.987 & $\begin{array}{l}\text { İskenderun Bay, } \\
\text { Mediterranean Sea }\end{array}$ & Erguden et al., 2009 \\
\hline & 29 & $7.0-24.1$ & 0.006 & 3.089 & 0.994 & Köyceğiz Lagoon & Present study \\
\hline \multirow{5}{*}{ E. encrasicolus } & 212 & & 0.0050 & 2.970 & 0.872 & Saros Bay & İşmen et al., 2007 \\
\hline & 759 & $5.8-14.0$ & 0.0008 & 3.822 & 0.950 & North Aegean Sea, Greece & Karachle and Stergiou, 2008 \\
\hline & 1588 & $5.9-14.6$ & 0.0124 & 2.711 & 0.944 & Black Sea & Kasapoğlu and Düzgüneş, 2013 \\
\hline & 68 & $7.0-11.3$ & 0.0070 & 2.917 & 0.999 & Homa Lagoon & Acarli et al., 2014 \\
\hline & 196 & $6.5-11.8$ & 0.0099 & 2.814 & 0.956 & Köyceğiz Lagoon & Present study \\
\hline \multirow{3}{*}{ G. niger } & 272 & $2.1-12.2$ & 0.0047 & 3.394 & 0.946 & $\begin{array}{l}\text { Northeastern } \\
\text { Mediterranean }\end{array}$ & Cicek et al., 2003 \\
\hline & 112 & $6.8-15.8$ & 0.0180 & 2.856 & 0.953 & Black Sea & Kasapoğlu and Düzgüneş, 2013 \\
\hline & 34 & $3.1-10.8$ & 0.0076 & 3.154 & 0.978 & Köyceğiz Lagoon & Present study \\
\hline \multirow{3}{*}{$\begin{array}{l}\text { M. barbatus } \\
\text { barbatus }\end{array}$} & 2693 & $5.3-19.0$ & 0.0074 & 3.123 & 0.962 & Black Sea & Kasapoğlu and Düzgüneş, 2013 \\
\hline & 1565 & $8.7-21.5$ & 0.0071 & 3.165 & 0.894 & $\begin{array}{l}\text { Northeastern } \\
\text { Mediterranean Sea }\end{array}$ & Özvarol, 2014 \\
\hline & 53 & $5.8-10.8$ & 0.0110 & 3.003 & 0.964 & Köyceğiz Lagoon & Present study \\
\hline \multirow{3}{*}{ O. niloticus } & 125 & $9.1-18.5$ & 0.0393 & 2.720 & 0.910 & Indus River, Pakistan & Naeem et al., 2010 \\
\hline & 261 & $11.5-47.0$ & 0.310 & 3.250 & 0.967 & $\begin{array}{l}\text { Eight floodplain lakes of } \\
\text { Agusan Marsh }\end{array}$ & Jumawan and Seronay, 2017 \\
\hline & 93 & $6.0-28.6$ & 0.0168 & 3.088 & 0.970 & Köyceğiz Lagoon & Present study \\
\hline \multirow{3}{*}{ S. aurata } & 59 & $14.6-45.0$ & 0.0266 & 2.736 & 0.966 & Gökova Bay, Aegean Sea & Ceyhan et al., 2009 \\
\hline & 105 & $13.5-18.3$ & 0.0090 & 3.150 & 0.999 & Homa Lagoon & Acarli et al., 2014 \\
\hline & 61 & $12.1-26.5$ & 0.0139 & 3.009 & 0.938 & Köyceğiz Lagoon & Present study \\
\hline \multirow{3}{*}{ S. rivulatus } & 84 & $15.5-25.0$ & 0.016 & 2.964 & 0.97 & Beymelek Lagoon & Sümer, 2012 \\
\hline & 2004 & $11.2-30.2$ & 0.0114 & 3.061 & 0.98 & Red Sea, Saudi Arabia & Gabr et al., 2018 \\
\hline & 37 & $8.2-19.9$ & 0.0115 & 3.079 & 0.979 & Köyceğiz Lagoon & Present study \\
\hline \multirow{4}{*}{ S. solea } & 21 & $11.0-22.1$ & 0.0098 & 3.002 & 0.988 & $\begin{array}{l}\text { Northern Aegean estuarine } \\
\text { systems }\end{array}$ & Koutrakis and Tsikliras, 2003 \\
\hline & 73 & $8.7-20.5$ & 0.0070 & 3.053 & 0.999 & Homa Lagoon & Acarli et al., 2014 \\
\hline & 1136 & $3.9-31.1$ & 0.0079 & 3.064 & 0.991 & Southern Aegean Sea & Cerim and Ateş, 2020 \\
\hline & 32 & $10.7-25.1$ & 0.0066 & 3.124 & 0.972 & Köyceğiz Lagoon & Present study \\
\hline \multirow{3}{*}{ T. ovatus } & 26 & $14.1-26.8$ & 0.0120 & 2.897 & 0.90 & Beymelek Lagoon & Sümer, 2012 \\
\hline & 33 & $15.7-44.0$ & 0.0089 & 2.937 & 0.994 & $\begin{array}{l}\text { Tropical north-eastern } \\
\text { Atlantic }\end{array}$ & Oliveira et al., 2015 \\
\hline & 30 & $14.9-26.9$ & 0.0113 & 2.901 & 0.971 & Köyceğiz Lagoon & Present study \\
\hline
\end{tabular}

Note: $n$ : sample size; TL: total length $(\mathrm{cm}) ; a$ : intercept; $b$ : slope of the regression line; $r^{2}$ : coefficient of determination. 


\section{Conclusion}

Consequently, growth parameters such as length-weight relationship provide some indication of resource utilization and the effectiveness of management strategies. Thus, fisheries management should be designed on biological data to understand the status and to manage of fish stocks. Köyceğiz Lagoon is important fishing area for local fisherman. This study provides the first basic information of the length-weight (LWRs) relationships of the studied species for the Köyceğiz Lagoon. These results will be useful for fisheries research, management and conservation in the Köyceğiz Lagoon.

\section{Acknowledgements}

I would like to thank Dr. Hasan CERIM and DALKO fishery cooperative for their helps.

\section{Compliance with Ethical Standards}

\section{Conflict of Interest}

The author declares that there is no conflict of interest.

\section{Ethical Approval}

This study was conducted in accordance with ethics committee procedures of animal experiments.

\section{References}

Abdallah, M. (2002). Length-weight relationship of fishes caught by trawl off Alexandria, Egypt. Naga The ICLARM Quarterly, 25(1): 19-20.

Acarli, D., Kara, A. \& Bayhan, B. (2014). Length-weight relations for 29 fish species from Homa Lagoon, Aegean Sea, Turkey. Acta Ichthyologica et Piscatoria, 44(3): 249257. https://doi.org/10.3750/AIP2014.44.3.09

Aka, Z., Koç, H. T. \& Turan, C. (2004). A study of the growth of the Anchovy Engraulis encrasicolus, Linnaeus (1758) in Turkish Seas. Pakistan Journal of Biological Science, 7(7): 1121-1126. https://doi.org/10.3923/pjbs.2004. $\underline{1121.1126}$

Ates, C., Cerim, H. \& Celik, M. (2017). Length-weight relationships of commercial indigenous and Lessepsian fishes in Gökova Bay, Turkey. Cahiers de Biologie Marine, 58(1): 43-47. https://doi.org/10.21411/CBM.A. 6374FD88

Bagenal, T. B. \& Tesch, F. W. (1978). Age and growth (pp.101136). In: Methods for assessment of fish production in fresh waters. IBP Handbook No. 3. T. Bagenal (Ed.). Oxford, UK: Blackwell Scientific Publications.
Bianchi, C. N. (1988). Caratterizzazione bionomica delle lagune costiere Italiane. Acqua \& Aria, 4: 15-20.

Bilge, G., Yapici, S., Filiz, H. \& Cerim, H. (2014). Weight-length relationshions for 103 fish species from the southern Aegean Sea, Turkey. Acta Ichthyologica et Piscatoria, 44(3): 263-269. https://doi.org/10.3750/AIP2014.44.3. $\underline{11}$

Bok, T. D., Gokturk, S. D. Kahraman, A. E. Alicli, T. Z. Acun, T. \& Ates, C. (2011). Length-weight relationships of 34 fish species from the Sea of Marmara, Turkey. Journal of Animal and Veterinary Advances, 10(23): 3037-3042. https://doi.org/10.3923/javaa.2011.3037.3042

Buhan, E. (1998). Development of lagoon management of Köyceğiz Lagoon system by researching present situation and grey mullet populations. Aquaculture Research Institute of Ministry of Agriculture, Bodrum. Serial B, 3: 1-347.

Can, M. F., Basusta, N. Cekic, M. (2002). Weight-length relationships for selected fish species of the small-scale fisheries off the south coast of Iskenderun Bay. Turkish Journal of Veterinary and Animal Sciences, 26(5): 11811183.

Cerim, H. \& Ateş, C. (2020). Age, growth and length-weight relations of common sole (Solea solea Linnaeus, 1758) from Southern Aegean Sea. Aquatic Sciences and Engineering, 35(2): 36-42. https://doi.org/10.26650/ ASE2020596672.

Ceyhan, T., Akyol, O. \& Erdem, M. (2009). Length-weight relationships of fishes from Gökova Bay, Turkey (Aegean Sea). Turkish Journal of Zoology, 33: 69-72. https://doi.org/10.3906/zoo-0802-9

Cicek, E., Avsar, D., Yeldan, H. \& Ozutok, M. (2006). Lengthweight relationships for 31 teleost fishes caught by bottom trawl net in the Babadillimani Bight (northeastern Mediterranean. Journal of Applied Ichthyology, 22(4): 290-292. https://doi.org/10.1111/j. 1439-0426.2006.00755.x

Crec'hriou, R., Neveu, R. \& Lenfant, P. (2013). Length-weight relationship of main commercial fishes from the French Catalan coast. Journal of Applied Ichthyology, 29(5): 1191-1192. https://doi.org/10.1111/jai.12320

Dimitriadis, C. \& Konstantinidou, F. I. (2018). Length-weight relations for 20 fish species (Actinopterygii) from the Southern Ionian sea, Greece. Acta Ichthyologica et Piscatoria, 48(4): 415-417. https://doi.org/10.3750/ AIEP/02466 
Djabali, F., Mehailia, A., Koudil, M. \& Brahmi, B. (1993). Empirical equations for the estimation of natural mortality in Mediterranean teleosts. Naga, The ICLARM Quarterly, 16(1): 35-37.

Dulčić, J. \& Kraljević, M. (1996). Weight-length relationship for 40 fish species in the eastern Adriatic (Croatian waters). Fisheries Research, 28(3): 243-251. https://doi.org/10. 1016/0165-7836(96)00513-9

Dulčić, J. \& Glamuzina, B. (2006). Length-weight relationships for selected fish species from three eastern Adriatic estuarine systems (Croatia). Journal of Applied Ichthyology, 22(4): 254-256. https://doi.org/10.1111/j. 1439-0426.2006.00633.x

Erguden, D., Turan, C. \& Gurlek, M. (2009). Weight-length relationships for 20 lessepsian fish species caught by bottom trawl on the coast of Iskenderun Bay (NE Mediterranean Sea, Turkey). Journal of Applied Ichthyology, 25(1): 133-135. https://doi.org/10.1111/ j.1439-0426.2008.01198.x

Froese, R. (2006). Cube law, condition factor and weight-length relationships: history, meta-analysis and recommendations. Journal of Applied Ichthyology, 22(4): 241-253. https://doi.org/10.1111/j.1439-0426.2006. 00805.x

Froese, R. \& Pauly, D. (Eds.) (2017). FishBase. World Wide Web electronic publication. Retrieved on January 31, 2018 from www.fishbase.org.

Gabr, M. H., Bakaili, A. S. \& Mal, A. O. (2018). Growth, mortality and yield per recruit of the rabbit fish Siganus rivulatus (Forsskål 1775) in the red sea coast of Jeddah, Saudi Arabia. International Journal of Fisheries and Aquatic Studies, 6(1): 87-96.

Ghailen, H., Abdallah, H., Hassan, A., Mourad, C., Abderrahmen, B. \& Othman, J. (2010). Length-weight relationships for 13 fish species from the Gulf of Gabes (Southern Tunisia, Central Mediterranean). African Journal of Biotechnology, 9(37): 6177-6181.

Giacalone, V. M., D’Anna, G., Badalamenti, F. \& Pipitone, C. (2010). Weight-length relationships and condition factor trends for thirty-eight fish species in trawled and untrawled areas off the coast of northern Sicily (central Mediterranean Sea). Journal of Applied Ichthyology, 26(6): 954-957. $\quad$ https://doi.org/10.1111/j.1439$\underline{0426.2010 .01491 . \mathrm{x}}$
Goncalves, J. M. S., Bentes, L., Lino, P. G., Ribeiro, J., Canario, A. V. M. \& Erzini, K. (1997). Weight-length relationships for selected fish species of the small-scale demersal fisheries of the south and south-west coast of Portugal. Fisheries Research, 30: 253-256. https://doi.org/10.1016/S0165-7836(96)00569-3

Gökçe, G., Çekiç, M. \& Filiz, H. (2010). Length-weight relationships of marine fishes off Yumurtalık coast (İskenderun Bay), Turkey. Turkish Journal of Zoology, 34(1): 101-104. https://doi.org/10.3906/zoo-0905-33

İlkyaz, A. T., Metin, G., Soykan, O. \& Kinacigil, H. T. (2008). Length-weight relationship of 62 fish species from the Central Aegean Sea, Turkey. Journal of Applied Ichthyology, 24(6): 699-702. https://doi.org/10.1111/j. 1439-0426.2008.01167.x

İşmen, A., Özen, O., Altinagac, U., Özekinci, U. \& Ayaz, A. (2007). Weight-length relationships of 63 fish species in Saros Bay, Turkey. Journal of Applied Ichthyology 23(6): 707-708. $\quad$ https://doi.org/10.1111/j.1439-0426.2007. 00872.x

Jumawan, J. C. \& Seronay, R. A. (2017). Length-weight relationships of fishes in eight floodplain lakes of Agusan Marsh, Philippines. Philippine Journal of Science, 146(1): 95-99.

Karachle, P. K. \& Stergiou, K. I. (2008). Length-length and length-weight relationships of several fish species from the North Aegean Sea (Greece). Journal of Biological Research-Thessaloniki, 10: 149-157.

Kasapoglu, N. \& Duzgunes, E. (2013). Length-weight relationships of marine species caught by five gears from the Black Sea. Mediterranean Marine Science, 15(1): 95100. https://doi.org/10.12681/mms.463

Keskin, Ç. \& Gaygusuz, Ö. (2010). Length-weight relationships of fishes in shallow waters of Erdek Bay (Sea of Marmara, Turkey). European Journal of Biology, 69(2): 87-94.

Koutrakis, E. T. \& Tsikliras, A. C. (2003). Length-weight relationships of fishes from three northern Aegean estuarine systems (Greece). Journal of Applied Ichthyology, 19(4): 258-260. https://doi.org/10.1046/j. 1439-0426.2003.00456.x

Maci, S., Longo, E. \& Basset, A. (2012). Length-weight relationships for 24 selected fish species from a non-tidal lagoon of the southern Adriatic Sea (Italy). Transitional Waters Bulletin, 3(3): 1-9. https://doi.org/10.1285/ i1825229Xv3n3p1 
Mahé, K., Bellamy, E., Delpech, J. P., Lazard, C., Salaun, M., Vérin, Y., Coppin, F. \& Travers-Trolet, M. (2018). Evidence of a relationship between weight and total length of marine fish in the North-eastern Atlantic Ocean: Physiological, spatial and temporal variations. Journal of the Marine Biological Association of the United Kingdom, 98(3): 627-625. https://doi.org/10.1017/ S0025315416001752.

Mehak, A., Mu, Y., Mohsin, M., Noman, M. \& Nazir, K. (2017). Population dynamics of Nile Tilapia (Oreochromis niloticus) at Chashma Barrage, Pakistan. Indian Journal of Geo-Marine Sciences, 46(1): 206-210.

Miththapala, S. (2013). Lagoons and Estuaries. Coastal Ecosystems Series (Vol 4). 73 p. IUCN Sri Lanka Country Office, Colombo.

Morato, T., Afonso, P., Lourinho, P., Barreiros, J. P., Santos, R. S. \& Nash, R. D. M. (2001). Length-weight relationships for 21 coastal fish species of the Azores, north-eastern Atlantic. Fisheries Research, 50(3): 297-302. https://doi.org/10.1016/S0165-7836(00)00215-0

Moutopoulos, D. K. \& Stergiou, K. I. (2002). Length-weight and length-length relationships of fish species from the Aegean Sea (Greece). Journal of Applied Ichthyology, 18(3): 200-203. $\quad$ https://doi.org/10.1046/j.14390426.2002.00281.x

Moutopoulos, D. K., Ramfos, A., Mouka, A. \& Katselis, G. (2013). Length-weight relations of 34 fish species caught by small-scale fishery in Korinthiakos Gulf (Central Greece). Acta Ichthyologica et Piscatoria, 43(1): 57-64. https://doi.org/10.3750/AIP2013.43.1.08

Naeem, M, Salam, A., Gillani, Q. \& Ishtiaq, A. (2010). Lengthweight relationships of Notopterus notopterus and introduced Oreochromis niloticus from the Indus River, southern Punjab, Pakistan. Journal of Applied Ichthyology, 26(4): 620. http://doi.org/10.1111/j.14390426.2010.01480.x

Nobile, A. B., Brambilla, E. M., de Lima, F. P., Freitas-Souza, D., Bayona-Perez, I. L. \& Carvalho, E. D. (2015). Lengthweight relationship of 37 fish species from the Taquari River (Paranapanema Basin, Brazil). Journal of Applied Ichthyology, 31(3): 580-582. https://doi.org/10.1111/ jai.12761

Oliveira, M. T., Santos, M. N., Coelho, R., Monteiro, V., Martins, A. \& Lino, P. G. (2015). Weight-length and length-length relationships for reef fish species from the Cape Verde Archipelago (tropical north-eastern Atlantic). Journal of Applied Ichthyology, 31(1): 236-241. https://doi.org/10.1111/jai.12497
Özvarol, Y. (2014). Length-weight relationships of 14 fish species from the Gulf of Antalya (northeastern Mediterranean Sea, Turkey). Turkish Journal of Zoology, 38(3): 342-346. https://doi.org/10.3906/zoo-1308-44

Pauly, D. (1984). Fish population dynamics in tropical water: $A$ manual for use with programmable calculators. Studies and Reviews 8. International Center for Living Aquatic Resources Management (ICLARM), Manila, Philippines. 325p.

Pauly, D. (1993). Editorial: Fishbyte section. Naga, The ICLARM Quarterly, 16(2-3): 1-26.

Ricker, W. E. (1975). Computation and interpretation of biological statistics of fish populations. Bulletin of the Fisheries Research Board of Canada, Bulletin 191, 400p.

Samsun, O., Samsun, N., Kalayci, F. \& Bilgin, S. (2006). A study on recent variations in the population structure of european anchovy (Engraulis encrasicolus L., 1758) in the Southern Black Sea. Ege University Journal of Fisheries Aquatic Science, 23(3-4): 301-306.

Sangun, L., Akamca, E. \& Akar, M. (2007). Weight-length relationships for 39 fish species from the north-eastern Mediterranean coast of Turkey. Turkish Journal of Fisheries and Aquatic Sciences, 7(1): 37-40.

Santos, M. N., Gaspar, M. B., Vasconcelos, P. \& Monteiro, C. C. (2002). Weight-length relationships for 50 selected fish species of the Algarve coast (southern Portugal). Fisheries Research, 59(1-2): 289-295. https://doi.org/10. 1016/S0165-7836(01)00401-5

Stergiou, K. I. \& Moutopoulos, D. K. (2001). A review of lengthweight relationships of fishes from Greek marine waters. Naga ICLARM Quarterly, 24(1\&2): 23-39.

Sümer, C. (2012). Length-weight relationships of 15 lagoon fish species collected in the Beymelek Lagoon (SW Turkey). Cahiers de Biologie Marine, 53(2): 185-188. https://doi.org/10.21411/CBM.A.BF51DD1C

Tesch, F. W. (1971). Age and growth (pp. 99-130). In: W. E. Ricker (Ed). Methods for assessment of fish production in fresh waters. Oxford, UK: Blackwell Scientific Publications.

Tsoumani, M., Liasko, R., Moutsaki, P., Kagalou, I. \& Leonardos, I. (2006). Length-weight relationships of an invasive cyprinid fish (Carassius gibelio) from 12 Greek lakes in relation to their trophic states. Journal of Applied Ichthyology, 22(4): 281-284. https://doi.org/10.1111/j. 1439-0426.2006.00768.x. 
Türkmen, M. (2003). Investigation of some population parameters of common sole, (Solea solea (L,. 1758)) from Iskenderun Bay. Turkish Journal of Veterinary and Animal Sciences, 27(2): 317-323.

Veiga, P., Machado, D., Almeida, C., Bentes, L., Monteiro, P., Oliveira, F., Ruano, M., Erzini, K. \& Gonçalves, J. M. S. (2009). Weight-length relationships for 54 species of the Arade estuary, southern Portugal. Journal of Applied Ichthyology, 25(4): 493-496. https://doi.org/10.1111/j. 1439-0426.2009.01230.x
Whitfield, A. K. (1999). Ichthyofaunal assemblages in estuaries: A South African case study. Reviews in Fish Biology and Fisheries, 9: 151-186. $\quad$ https://doi.org/10.1023/ A:1008994405375 